\title{
OS TERMOS TÉCNICOS MUSICAIS NOS SALMOS E AS SOLUÇÕES/OPÇÕES ENCONTRADAS EM EDIÇÕES DA BÍBLIA EM LÍNGUA PORTUGUESA
}

The Technical Musical Terms in the Psalms and the Solutions/Options Found in Editions of the Bible in Portuguese Language

Edson de Faria Francisco *

RESUMO: O livro dos Salmos contém vários termos técnicos musicais que aparecem normalmente nos títulos de diversos salmos. Em tais cabeçalhos, as unidades terminológicas indicam instrumento musical, modelo de cântico, melodia de cântico e título musical. A característica principal desses vocábulos é que são de significado desconhecido e são, também, autêntico desafio para a tradução. Este estudo é dedicado a analisar treze termos técnicos musicais que são registrados no texto bíblico hebraico do livro dos Salmos e de que maneira algumas edições bíblicas em língua portuguesa os interpretaram. Além do mais, este estudo aborda, ainda, que alternativa adotaram essas publicações bíblicas em português: transliteração ou tradução/interpretação.

PALAVRAS-CHAVE: Bíblia. Salmos. Hebraico. Tradução. Termos Técnicos Musicais.

ABSTRACT: The book of Psalms contains several technical musical terms that often appear in the titles of various psalms. In these headers, this terms indicate musical instrumentation, singing tone, melody and musical title. The main characteristic of these words is that they are of unknown meaning and present an authentic challenge for translation. This study is dedicated to analyzing thirteen technical musical terms that are recorded in the Hebrew text of the book of Psalms and how some biblical editions in Portuguese have interpreted them. Moreover, this

* Universidade Metodista de São Paulo, São Bernardo do Campo, SP, Brasil. 
study addresses what alternatives these biblical publications could have adopted in Portuguese: transliteration or translation/interpretation.

KEYWORDS: Bible. Psalms. Hebrew. Translation. Musical Technical Terms.

\section{Introdução}

$\mathrm{O}$

tema do presente artigo surgiu durante a produção do Antigo Testamento Interlinear Hebraico-Português, volume 4: Escritos (ATI) (Francisco, 2020), entre 2017 e 2019, aproximadamente, para a Sociedade Bíblica do Brasil (SBB). Em tal tomo consta o livro dos Salmos, sendo a primeira obra escriturística do bloco dos Escritos ou Hagiógrafos da Bíblia Hebraica. Na referida publicação, são elencados e comentados no capítulo "Dificuldades Textuais" os termos técnicos musicais registrados no livro dos Salmos (cf. abaixo) que são de difícil tradução e interpretação. Então, o assunto já teve um desenvolvido prévio recentemente, porém, a abordagem foi distinta da atual que está neste artigo. No estudo anterior, o enfoque foi principalmente relacionado, especificamente, com situações textuais. Além disso, no ATI foram usadas informações encontradas em literatura específica sobre crítica textual da Bíblia Hebraica.

A abordagem no presente texto é discutir como determinadas edições da Bíblia em português (cf. abaixo) solucionaram e/ou entenderam os diversos termos técnicos musicais encontrados em vários salmos, o que se revela um verdadeiro desafio de tradução do texto original hebraico para qualquer outro idioma. Isso se aplica especialmente ao grupo de itens lexicográficos relacionado com o universo da música nos Salmos. Além do mais, Francisco explica que determinados itens lexicais hebraicos, que denotam animais selvagens, instrumentos musicais, peças arquitetônicas, pesos e medidas, entre outras unidades lexicográficas da Bíblia Hebraica, são de tradução complexa. Ele explana que em diversos dicionários de hebraico bíblico são encontradas as seguintes explicações sobre alguns vocábulos de difícil tradução que são encontrados nos títulos dos Salmos: "significado incerto", "significado desconhecido", "anotação técnica inexplicável", "instrumento musical desconhecido" etc. (FRANCISCO, 2014, p. 117). Tais explicações e informações revelam a evidente complexidade de se traduzir o texto bíblico dos idiomas originais, hebraico, aramaico e grego.

Sobre o assunto, Fontinoy comenta que muitos salmos possuem cabeçalhos e existem informações musicais em alguns deles. Entretanto, não é sabido o significado de tais dados. Até hoje, essas ocorrências de cunho musical são objeto de inúmeros debates a respeito e não há certeza, ainda, sobre a sua real acepção original. Além disso, os tradutores das antigas versões bíblicas já não compreendiam as indicações musicais que são registradas 
nos Salmos (cf. abaixo). Teoricamente, alguns títulos podem remeter a

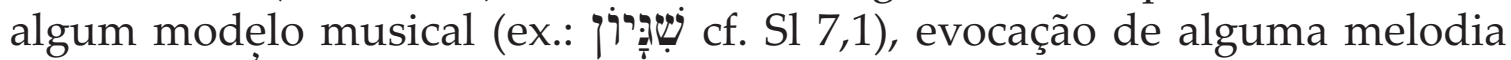

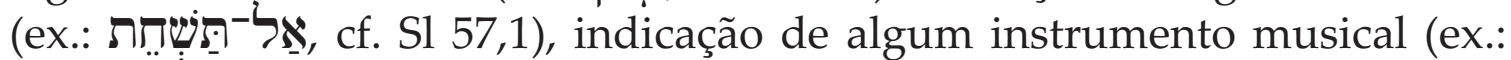

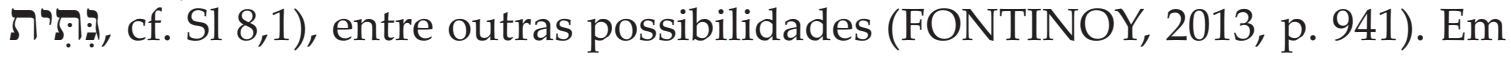
diversas edições da Bíblia, são encontradas em notas de rodapé algumas informações, tais como "significado incerto", concernente aos cabeçalhos achados em diversos salmos. Lipiński, comentando sobre tal espécie de informe, diz que isso revela as numerosas obscuridades do texto bíblico hebraico, mostrando o estado precário da tradição textual do livro dos Salmos (LipińsKI, 2013, p. 1204). Portanto, os termos técnicos musicais do referido livro escriturístico também são englobados na problemática textual da Bíblia Hebraica.

No presente texto, foram escolhidas sete edições da Bíblia em língua portuguesa: Antigo Testamento Interlinear Hebraico-Português (ATI), Bíblia de Jerusalém (BJ), A Bíblia: Salmos (BS), Nova Almeida Atualizada (NAA), Tanah Completo Hebraico e Português: Texto hebraico baseado no Códex de Alepo e tradução baseada no hebraico e à luz do Talmud e das fontes judaicas (Tanahn), Bíblia Sagrada-Tradução Brasileira (TB) e Bíblia-Tradução Ecumênica (TEB̈). Tais publicações bíblicas são produtos de diversas confissões religiosas, como católica, protestante e judaica. Estas obras são referidas neste estudo sempre por meio de abreviaturas dos seus títulos.

\section{Termos técnicos}<smiles>[TeH]</smiles>

O termo técnico musical ợ é de significado obscuro, constando setenta e uma vezes em trinta e nove salmos (cf. Sl 3,3; 9,17; 21,3; 32,4; 81,8; 143,6 etc.) e três vezes em Habacuque (cf. Hab 3,3.9.13) (Even-SHoshan, 1997 , p. 809), constituindo, assim, um dos termos musicais mais usados no livro de Salmos.

Geralmente, nos diversos dicionários dedicados ao hebraico bíblico nem sempre há alguma definição conclusiva sobre a referida unidade terminológica, além de constarem conjecturas. Kirst et al., Holladay, Alonso Schökel e Davidson apresentam as seguintes possibilidades: "termo técnico de significado incerto ou inexplicável", "anotação musical", "pausa na recitação"; "termo técnico suplementar em música e recitação"; "levanta!" (a voz em resposta ao instrumento), "cessa!", "parada!", "pausa!" (KiRst et Al., 2014, p. 168; Holladay, 2010, p. 364; Alonso SchöKel, 2004, p. 467; Davidson, 2018, p. 853). Brown, Driver e Briggs explanam que, provavelmente, o referido item lexicográfico teria começado a ser utilizado no final do período persa, em conexão com os trinta e nove salmos que 
eram usados com acompanhamento musical no culto público, para indicar

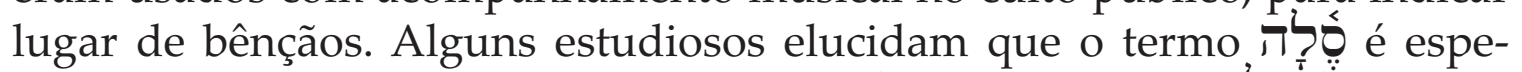

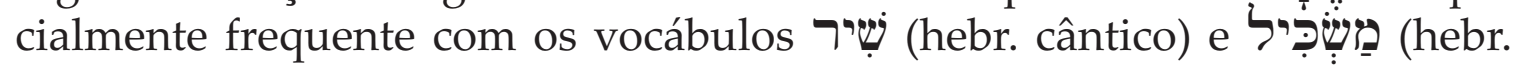
maskil), que são associados com execução musical (Brown, Driver e Briggs, 1996, p. 699-700). Koehler e Baumgartner explicam que, possivelmente, a unidade lexical em relevo teria relação com a palavra persa sala (cântico, som de cordas) e que, provavelmente, seria um termo técnico adicionado tardiamente, concernente ao estilo da música ou recitação. Normalmente, os hebraístas vinculam o item lexical em destaque à raiz verbal סלל (hebr. [pilpel] erguer, alçar, levantar). Eles comentam que poderia ser um

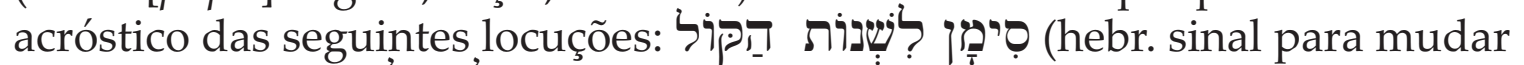

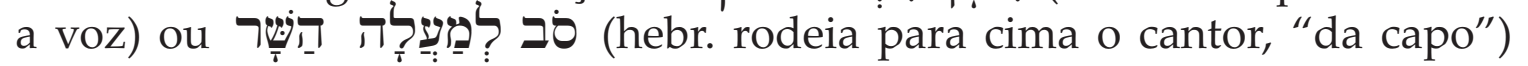
(Koehler e Baumgartner, 2001, p. 756). ${ }^{1}$ Clines e Jastrow presumem que talvez seja termo musical para indicar direção/orientação musical e optam em transliterar o termo como "selah" (Clines, 2009, p. 298; JAstrow, 2005, p. 993). Por fim, Mackenzie, Patterson e Fontinoy explanam que a unidade terminológica talvez seja uma anotação musical, mas de significado desconhecido, não sendo possível alguma tradução que seja segura, podendo ser interpretada como "elevação", "pausa" ou "inclinação" (MACKEnzie, 1984, p. 828; Patterson, 1998, p. 1046; Fontinoy, 2013, p. 941). Joüon e Muraoka comentam que é uma palavra inexplicável e Waltke e O'Connor dizem que é vocábulo de significado desconhecido, sendo encontrado somente nos Salmos e em Habacuque e conjecturam, ainda, que seja, aparentemente, uma espécie de exclamação (Joüon e Muraoka, 2009, § 93 d, n. 3, p. 257; WALtKe E O'ConNor, 2006, § 40.2.3 a, p. 681).

Algumas versões bíblicas clássicas, como a grega, a latina e a aramaica, interpretam o termo técnico da seguinte maneira: a Septuaginta interpre-

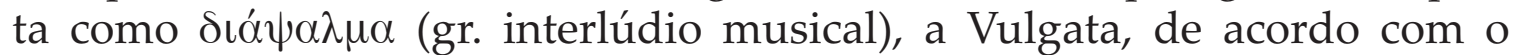
Psalterium Gallicanum, como diapsalma (lat. interlúdio musical) e de acordo com o Psalterium iuxta Hebraeos, como semper (lat. sempre) e o Targum

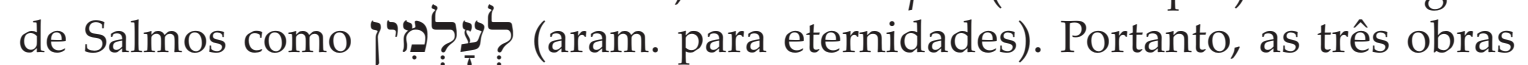
bíblicas apresentam alguma interpretação, sendo que os textos bíblicos grego e latino, mas segundo o Psalterium Gallicanum, apresentam a mesma solução, apenas os textos bíblicos latino, mas conforme o Psalterium iuxta Hebraeos, e aramaico possuem leituras distintas.

Nas diversas edições da Bíblia em português, são constatadas as seguintes alternativas de tradução para o termo ợ: no ATI é transliterado como "séla"; ${ }^{2}$ na $B J$, na TEB e na $B S$ é traduzido como "pausa" e na TB é trans-

\footnotetext{
1 "Da capo": expressão de origem italiana, significando desde o início (lit. "da cabeça"). Tal locução técnica musical indica, nas partituras musicais, que um determinado trecho executado deveria ser repetido desde o começo (Houaiss E VILLAR, 2009, p. 592).

2 O item lexicográfico ơ ợ possui tonicidade paroxítona, como indica o sinal colocado na penúltima sílaba. No ATI, a referida unidade lexical é transliterada como "séla", reproduzindo a tonicidade original hebraica (Francisco, 2020, p. x, n. 13).
} 
crito como "selá". Todavia, na NAA e na Tanah não há nenhuma opção de tradução para a palavra em destaque neste tópico. Além do mais, nenhuma edição bíblica em português acata alguma das opções encontradas nas três versões antigas da Bíblia, algumas optando em traduzir como "pausa" e outras decidindo transcrever como "séla" ou "selá". A tradução como "pausa", acatada por algumas edições bíblicas, poderia refletir, de alguma maneira, a opção da Septuaginta e da Vulgata, que traduzem o item lexical ơ como "interlúdio musical". Por fim, no ATI optou-se em adotar transliteração para o item lexicográfico ợ, pelo motivo de não ser possível tradução que possa corresponder ao significado exato do mesmo no texto bíblico hebraico. Tal procedimento também encontra respaldo em Kirst et al. e em Clines (cf. acima) (Francisco, 2020, p. xi).<smiles>[AlH2]</smiles>

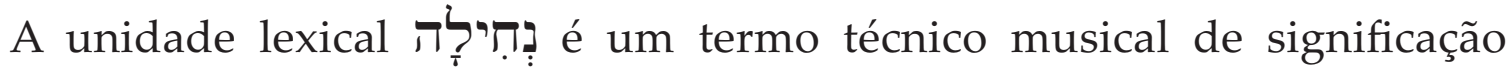
ignorada, além de ser um hapax legomenon, ${ }^{3}$ ocorrendo unicamente no Salmo 5,1 (Even-Shoshan, 1997, p. 751). No texto bíblico hebraico, a palavra aparece na forma plural, possuindo preposição separável e artigo

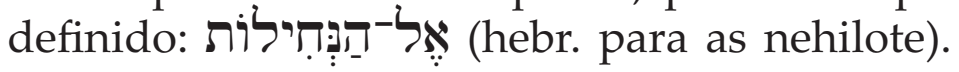

Nos dicionários de hebraico bíblico não é encontrada nenhuma acepção que seja definitiva a respeito da unidade lexical em relevo. Geralmente, são encontradas as seguintes informações: para Kirst et al., Holladay, Alonso Schökel e Davidson seria termo técnico musical de significado incerto ou inexplicado, sendo, talvez, "flauta" ou "gaita" (KIRST ET AL., 2014, p. 154; Holladay, 2010, p. 331; Alonso SchöKel, 2004, p. 428; Davidson, 2018, p. 458). Brown, Driver e Briggs explicam que se trata de termo de significado desconhecido e comentam que poderia haver alguma conexão com a חדרליל lexia (hebr. flauta). Por fim, eles cogitam que, possivelmente, seria alguma designação de uma melodia (Brown, Driver e Briggs, 1996, p. 636). Koehler e Baumgartner, não fornecendo nenhuma significação para o item lexicográfico em discussão, informam que se trata de termo técnico inexplicado na música ou na hinologia, conjeturando que poderia ser interpretado como "tocado na flauta", associando à palavra חָלִ "מדיל (hebr. flauta) ou como "contra doença", filiando ao vocábulo hipotético (hebr. doenças) (Koehler e Baumgartner, 2001, p. 686). Clines fornece três acepções possíveis: 1. "flauta", conectando à palavra חָל

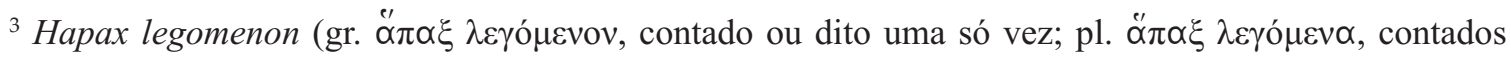
ou ditos uma só vez): termo técnico usado pela crítica textual para designar o vocábulo ou expressão que aparece uma única vez ao longo de uma determinada obra literária (Tov, 2012, p. 67; idem, 2017, p. 68; Würthwein, 1995, p. 28; Khan, 2013, p. 67; Fischer, 2013, p. 304; Martín Contreras e Seijas de los Ríos-Zarzosa, 2010, p. 128; Brotzman e Tully, 2016, p. 101; Francisco, 2008, p.

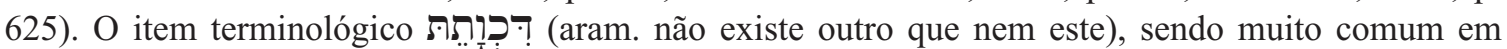
textos massoréticos, corresponde à locução hapax legomenon, que é usada na literatura dedicada à crítica textual (OfER, 2002, p. 33; idem, 2019, p. 16 e 50).
} 
2. "doença", a vinculando à raiz verbal I הלח (hebr. [qal] estar doente, ficar doente, adoecer); 3. "herança", a relacionando com a raiz verbal נחלחל (hebr. [qal] herdar) (CLINEs, 2009, p. 268). Coppes diz que se trata de um termo musical, podendo ser, talvez, relacionado com a palavra חדיליל (hebr. flauta) (Coppes, 1998, p. 948).

As versões clássicas da Bíblia interpretam de maneiras distintas a expressão

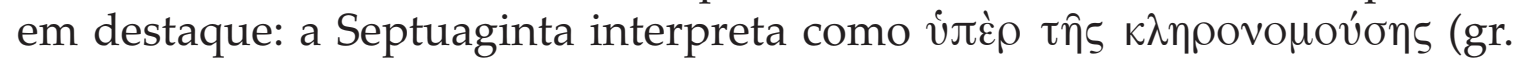
pela que recebe em herança), a Vulgata, conforme o Psalterium Gallicanum, como pro ea quae hereditatem (lat. por aquela que obtém a herdade) e conforme o Psalterium iuxta Hebraeos, como pro hereditatibus (lat. por herdades)

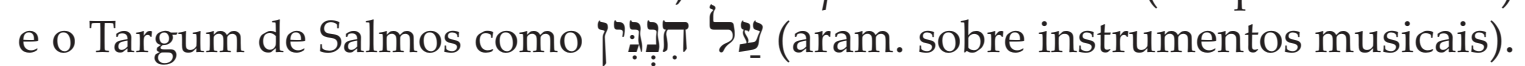
Portanto, os textos bíblicos grego, latino e aramaico optam em interpretar a palavra cada qual à sua maneira, em virtude das dificuldades de tradução do texto original hebraico.

Nas várias edições bíblicas em língua portuguesa, são constatadas as

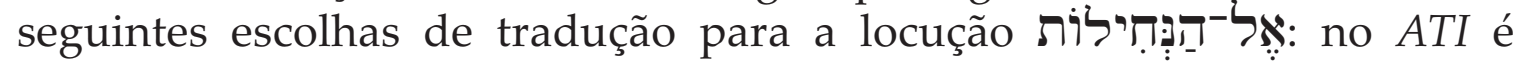
transcrita como "nehilote"; na $B J$, na TB, na NAA e na TEB é vertida como "flautas" na BS e na Tanah é traduzida como "instrumentos de sopro". Então, a maioria das publicações da Bíblia opta em traduzir como "flautas", refletindo uma das alternativas de tradução encontradas em vários dicionários de hebraico bíblico citados neste tópico (cf. acima). Por não haver ainda algum consenso entre os hebraístas sobre tal problemática de ordem lexicográfica, decidiu-se por simples transliteração do supracitado item lexical como "nehilote" no ATI (Francisco, 2020, p. XII).

\section{שִשְמִִינִית}

O vocábulo שִשמִמינִית é um termo técnico musical de significado incógnito, sendo registrado três vezes na Bíblia Hebraica (cf. Sl 6,1; 12,1; 1Cr 15,21) (Even-Shoshan, 1997, p. 1173). No texto bíblico hebraico, a palavra possui

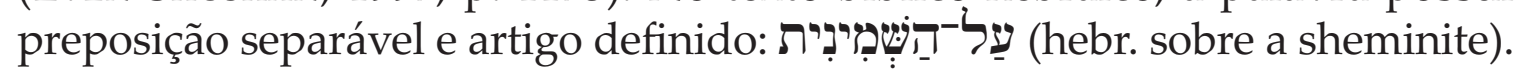

Normalmente, nas diversas obras lexicográficas dedicadas ao hebraico bíblico são encontradas suposições a respeito da palavra em destaque: para Kirst et al., Holladay, Alonso Schökel e Davidson seria "oitava" e "(o instrumento de) oito cordas" (Kirst et AL., 2014, p. 255; Holladay, 2010, p. 533-534; Alonso SchöKel, 2004, p. 679; Davidson, 2018, p. 1037). Brown, Driver e Briggs presumem que seria "à oitava chave" ou "sobre a oitava", mas eles dizem que tais possibilidades são totalmente duvidosas (Brown, Driver e Briggs, 1996, p. 1033). Koehler e Baumgartner comentam que é termo técnico em associação com a raiz verbal I בצח (hebr. [piel] dirigir, supervisionar), sendo interpretado, literalmente, como "(de acordo com) a oitava"; eles listam ainda as seguintes possibilidades: 1 . "um instrumento musical de oito cordas"; 2. "a oitava corda de um instrumento 
musical"; 3. "uma oitava inferior"; 4. "um termo relacionado com alguma festividade de ano novo"; 5. "uma alusão ao nome gentílico simronita, sendo derivado do nome da cidade canaanita Sinrom" (cf. Js 11,1; 19,15); porém, eles concluem que tais possibilidades não são decisivas (KoEHLER E BAUMgartNer, 2001, p. 1562). Clines explica que significaria "sobre ou de acordo com a sheminite", denotando, talvez, um instrumento musical de oito cordas, tocado na oitava chave ou cantado em oitava inferior (CLINES, 2009, p. 468). Jastrow define apenas como "oitava" (JAstrow, 2005, p. 1596). Mackenzie, Wolf e Fontinoy deduzem, mas demonstrando algum grau de dúvida, que seria "a oitava" ou "harpa de oito cordas" (Mackenzie, 1984, p. 828; Wolf, 1998, p. 1585; FontinoY, 2013, p. 941).

A seguinte situação é encontrada nas antigas versões da Bíblia: a Sep-

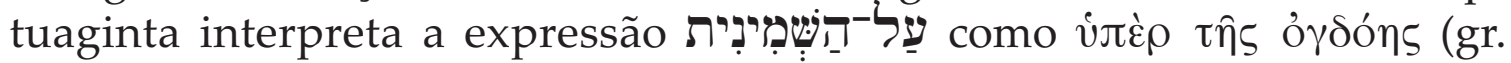
sobre a oitava), a Vulgata, de acordo com o Psalterium Gallicanum, como pro octava (lat. para a oitava) e de acordo com o Psalterium iuxta Hebraeos, como super octava (lat. sobre a oitava) e o Targum de Salmos como

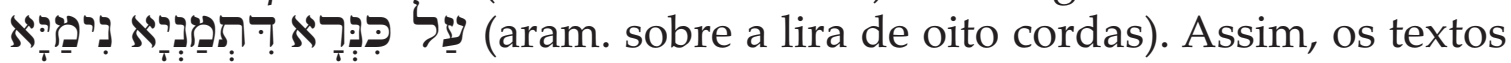
bíblicos grego, latino e aramaico parecem apresentar duas possibilidades de leitura: 1. um instrumento musical de oito cordas (Targum de Salmos) e 2. a oitava corda de um instrumento musical (Septuaginta e Vulgata).

O seguinte quadro é verificado nas diversas edições da Bíblia em português

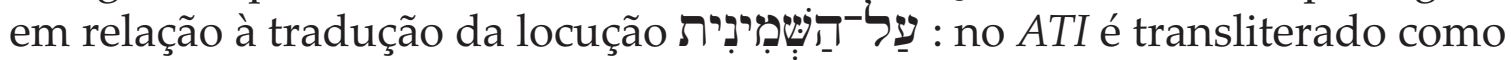
"sobre a sheminite"; na BJ e na $B S$ é traduzida como "sobre a oitava"; na $N A A$ e na TEB é vertida como "de oito cordas"; na TB é transcrita como "seminite" e na Tanah é traduzida como "música instrumental". Por motivo da evidente indecisão por parte dos hebraístas e por falta de alguma definição que pudesse ser indiscutível, no ATI o item lexical é simplesmente transliterado como "sheminite", seguindo uma das opções fornecidas por Clines (cf. acima) (Francisco, 2020, p. xIII).

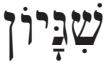

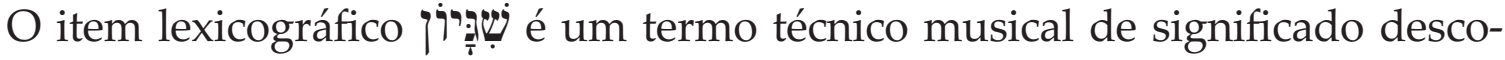
nhecido. Trata-se de item terminológico técnico para um tipo específico de canção litúrgica, sendo registrado apenas duas vezes no texto bíblico hebraico de tradição massorética (cf. Hab 3,1; Sl 7,1) (Even-Shoshan, 1997, p. 1114).

Os hebraístas nem sempre fornecem acepção possível e, quando o fazem, oferecem as seguintes escolhas, mas sempre demonstrando dúvidas: Kirst et al. supõem que seria "lamento" ou "nênia". Holladay comenta, apenas, que é sobrescrito obscuro. Alonso Schökel pensa que seria "intercessão por inadvertências". Davidson conjetura que talvez se trate de um salmo composto durante uma peregrinação e perseguição (KIRST ET AL., 2014, p. 244; Holladay, 2010, p. 513; Alonso SchöKel, 2004, p. 658; Davidson, 
2018, p. 1008). Brown, Driver e Briggs não fornecem significação nenhuma e afirmam que é palavra duvidosa; eles esclarecem que o vocábulo seria derivação da raiz verbal שגוה (hebr. [qal] extraviar-se, desviar-se, cambalear) ou da raiz verbal ששוע (hebr. [pual] enlouquecer-se; [hitpael] estar louco) e denotaria um cântico selvagem, passional, com mudanças rápidas de ritmo; eles conjecturam que a lexia deveria ser lida como נִבְינוֹ (hebr. instrumentos de música) (Brown, Driver e Briggs, 1996, p. 993). Koehler e Baumgartner, da mesma maneira não fornecendo nenhuma acepção conclusiva, comentam que a etimologia e o significado exato são desconhecidos, e que seria um termo técnico para um tipo específico de cântico cúltico; eles presumem que possa ter relação com o vocábulo acádico šigĥu (lamentação) ou árabe saja (w) (estimular para grande excitação); eles concluem que não é possível saber de maneira definitiva a real significação da unidade lexicográfica em realce (Koehler e Baumgartner, 2001, p. 1414-1415). Clines fornece três opções possíveis de interpretação: 1. "canção de êxtase"; 2. "canção de lamentação"; 3. "canção de excitamento" (Clines, 2009, p. 449). Jastrow

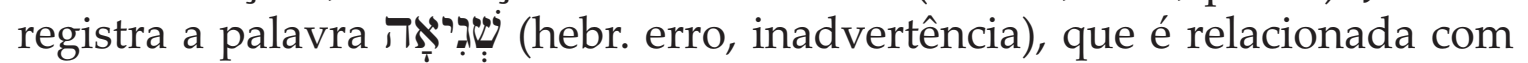
o Salmo 7 na obra Midrash Tehllim (Midrash para os Salmos) (Jastrow, 2005, p. 1522). Mackenzie e Patterson comentam somente que é vocábulo de significado desconhecido (Mackenzie, 1984, p. 828; PAtTerson, 1998, p. 1046).

As versões clássicas do texto bíblico possuem as seguintes alternativas de

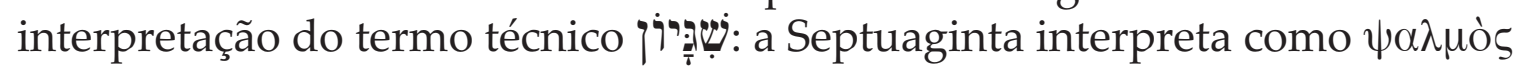
(gr. salmo), a Vulgata, segundo o Psalterium Gallicanum, como psalmus (lat. salmo) e segundo o Psalterium iuxta Hebraeos, como pro ignoratione (lat. pela ignorância) e o Targum de Salmos como אִּ (aram. discurso alto). As versões grega e latina (o Psalterium Gallicanum) concordam entre si ao traduzirem a lexia técnica como salmo. Por outro lado, as versões aramaica e latina (o Psalterium iuxta Hebraeos) possuem outras interpretações, vertendo como "pela ignorância" e "discurso alto", respectivamente.

O item lexicográfico eque é transliterado como "shiggaion" no ATI, como "sigaiom" na TB e como "shigaion" na Tanah. Na BS e na BJ a mesma lexia é traduzida como "lamentação", na TEB como "confissão" e na NAA como "cântico". No ATI é encontrada transliteração simplificada para o item lexicográfico como "shiggaion", em virtude das dificuldades de tradução (Francisco, 2020, p. xIII). Inclusive, o ATI, a TB e a Tanah adotam formas transliteradas similares (cf. acima), apenas diferindo entre si nos pormenores de transcrição fonética das consoantes e dos sinais vocálicos hebraicos. ${ }^{4}$

\footnotetext{
${ }^{4}$ Transcrição fonética de letras de um alfabeto para caracteres de outro (ex.: transcrição fonética de uma palavra escrita originalmente com as letras do abecedário hebraico, sendo, posteriormente, transcrita

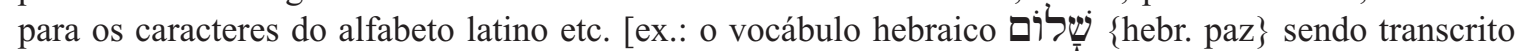
com as letras do abecedário latino como shalôm] (FrAncisco, 2014, p. 118) (obs.: a transliteração de tal item lexical, mas de acordo com a norma acadêmica vigente, é da seguinte maneira: šălôm).
} 
A unidade lexical ạ: é um termo técnico musical de significação obscura, sendo registrado três vezes nos Salmos (cf. Sl 8,1; 81,1; 84,1) (Even-Shoshan, 1997, p. 245). Nas três passagens bíblicas, o item lexicográfico é registrado com preposição separável e artigo definido: פַַל (hebr. sobre a guittite).

Comumente, não é encontrada nos dicionários de hebraico bíblico alternativa para tradução que seja indiscutível para tal item lexicográfico: Kirst et al. pensam que seria termo musical desconhecido, talvez significaria "harpa de Gate". Holladay cogita que se trate de termo musical desconhecido, talvez denotaria 1. "instrumento gatita"; 2 o item lexical significaria "perto dos lagares", em referência à festa dos Tabernáculos; 3. a palavra seria alguma referência ao festival de Ano Novo. Alonso Schökel comenta que é termo musical de significado duvidoso, talvez denotando "segundo a

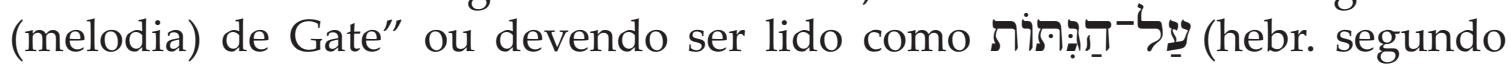
a [melodia] dos lagares). Davidson supõe que seria nome de um instrumento musical (Kirst et al., 2014, p. 45; Holladay, 2010, p. 89; Alonso SснӧкеL, 2004, p. 145; DAvidson, 2018, p. 311). Brown, Driver e Briggs conjecturam que seria item lexical derivado da hipotética raiz verbal (hebr. [qal] bater) e significaria 1. "sobre a (lira) gatita"; 2. "para a (melodia) gatita"; 3. o termo é para ser lido como (hebr. os lagares), de acordo com a leitura da Septuaginta e da Vulgata (cf. abaixo) (Brown, Driver e BRIGGS, 1996, p. 388). Koehler e Baumgartner explanam que é termo técnico musical incerto, indicando 1. "instrumento de Gate"; 2. o vocábulo significaria "perto dos lagares", em referência à festa dos Tabernáculos, também segundo a leitura das versões bíblicas grega e latina, que leem

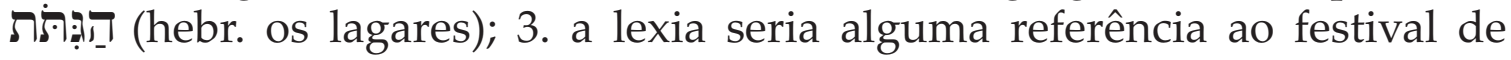
Ano Novo (Koehler e Baumgartner, 2001, p. 206-207). Clines translitera o item terminológico como "guittite" e explica que significaria, talvez, um instrumento ou melodia associada com (músico de) Gate ou com lagares (Clines, 2009, p. 72). Jastrow pressupõe que seria "lagar", porém, ele não relaciona com o caso do Salmo 8,1 (Jastrow, 2005, p. 275). Para Mackenzie seria "harpa de Gate", "a gitei", para Wolf seria melodia ou instrumento musical, talvez relacionado com a cidade filisteia de Gate, transliterando o termo como "gitite" e para Fontinoy seria "sobre a harpa de Gate" ou "sobre (a ária de) a guitita" (MAckenZIE, 1984, p. 828; Wolf, 1998, p. 589; FonTINOY, 2013, p. 941).

O item lexical em destaque neste tópico é traduzido pelas versões bíblicas clássicas da seguinte maneira: a Septuaginta verte como viлk̀ $\tau \hat{\omega} v \lambda \eta v \hat{\omega} v$ (gr. sobre os lagares), a Vulgata, de acordo com o Psalterium Gallicanum e o Psalterium iuxta Hebraeos, como pro torcularibus (lat. para os lagares) e

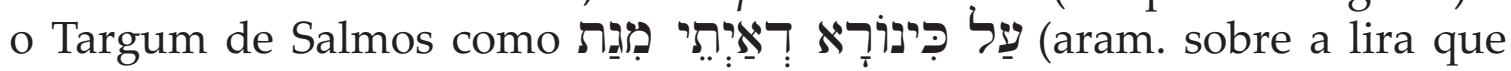
trouxe de Gate). As versões grega e latina apresentam a mesma solução 
para o caso, ao verterem a citada palavra como "lagares", a vinculando

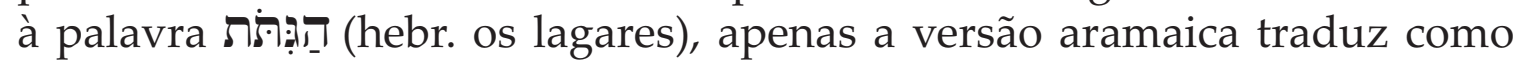
"lira de Gate", a conectando ao vocábulo הְְַּּּתִת (hebr. a guittite).

A maioria das publicações da Bíblia em língua portuguesa trata o vocábulo עַל como algum objeto musical relacionado a Gate, geralmente adotando transcrições fonéticas: no ATI é transliterado como "sobre a guittite", na TB como "em gitite" e na TEB como "na guitit". Na Tanah é traduzido como "acompanhado com o instrumento guitit", na BS como "com o instrumento Gitit" e na BJ como "sobre a... de Gat". Apenas na $N A A$ a palavra é vertida como "os lagares", a vinculando com a lexia הַ:ּרוּת (hebr. os lagares), conforme a Septuaginta e a Vulgata. Para a BJ a unidade lexical denotaria, talvez, uma harpa ou uma melodia de procedência filisteia ( $B J$, p. 869 , n. e). De acordo com a TEB, se trata de item lexicográfico desconhecido, que conforme as antigas versões bíblicas, seria um instrumento musical da cidade de Gate ou um cântico de vindima e de lagar (TEB, p. 1018, n. e). Por não haver consonância entre os estudiosos em relação ao assunto, no ATI é adotada transliteração para o supracitado termo técnico musical, seguindo a escolha fornecida por Clines (cf. acima) (Francisco, 2020, p. XIV).

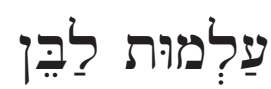

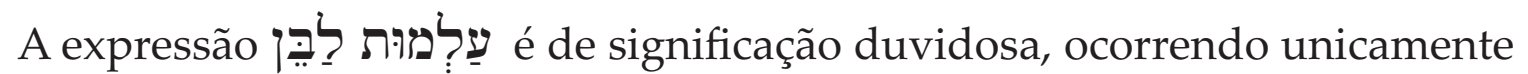
no Salmo 9,1 (Even-Shoshan, 1997, p. 882). Tal locução significaria, literalmente, algo como "sobre a morte do filho".

As seguintes opiniões, sugestões e suposições a respeito da expressão em destaque são encontradas nos dicionários de hebraico bíblico: Kirst et al. informam que é de significado desconhecido. Holladay explica que se trata de notação técnica inexplicada. Alonso Schökel não registra a locução. Davidson, dizendo que é de significado desconhecido, propõe ler que significaria algo como "vozes femininas" (KIRST ET AL., 2014, p. 181; Holladay, 2010, p. 389; Davidson, 2018, p. 726). Brown, Driver e Briggs, não fornecendo nenhuma acepção para tradução, conectam a expres-

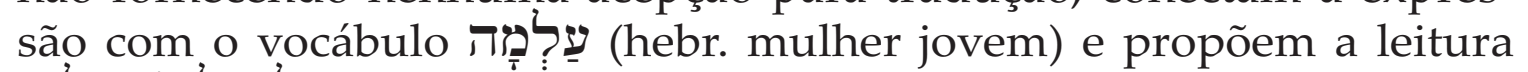

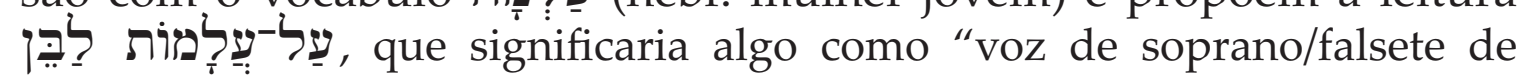
meninos" (Brown, Driver e Briggs, 1996, p. 761). Koehler e Baumgartner, também não oferecendo nenhuma alternativa para tradução, afirmam que é de significação incerta; eles informam que em muitos manuscritos hebraicos medievais é achada a leitura עַל על מוּר (hebr. sobre a morte de) (Koehler e Baumgartner, 2001, p. 836). Clines conecta, mas com dúvidas, a expressão com a raiz verbal עלם (hebr. [qal] ocultar); ele propõe as seguintes possibilidades de interpretação: 1. "ocultação", que seria um termo musical, talvez, denotando sotto voce (it. em voz baixa); 2. "jovem"; 3. "instrumento musical". Clines informa, ainda, que em determinados 
manuscritos hebraicos medievais é encontrada a leitura עַל לַחמוּת , que significaria algo como "sobre a morte de (Labben)", "sobre a morte do filho" ou "sobre a morte de Ben" (Clines, 2009, p. 328). Mackenzie interpreta a supracitada expressão como "a morte do filho" (MACKENZIE, 1984, p. 828).

As três versões bíblicas antigas oferecem as seguintes interpretações a respeito da expressão registrada no cabeçalho do Salmo 9,1: a Septua-

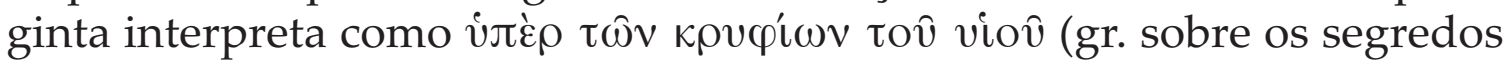
do filho), a Vulgata, segundo o Psalterium Gallicanum, como pro occultis filii (lat. pelos segredos do filho) e segundo o Psalterium iuxta Hebraeos, como pro morte filii (lat. pela morte do filho) e o Targum de Salmos como

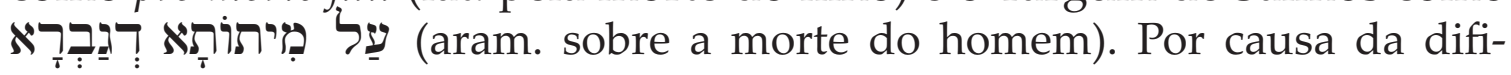
culdade de tradução, as três obras bíblicas apresentam interpretação em vez de tradução para o trecho.

Parte das versões da Bíblia em português opta em transliterar e parte

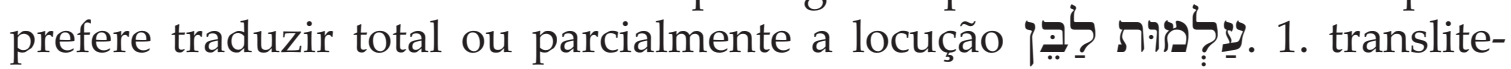
ração: ATI: "almute labben"; TB: "mutelabem"; TEB: "'almut labben". 2. tradução parcial: Tanah: "sobre a morte de Laben". 3. tradução total: BJ: "para oboé e harpa"; BS: "sobre a morte do filho" e NAA: "segundo a melodia 'a morte para o filho'". Na $B J$ a expressão é traduzida como "para oboé e harpa" no próprio corpo do texto e há uma anotação de rodapé com a tradução "sobre (a ária de) morrer para o filho" (BJ, 2002, p. 870, n. d). Na TEB consta a transcrição "'almut labben" no próprio corpo do texto e há uma nota de rodapé com a tradução "sobre os segredos do filho e sobre a morte do filho" (TEB, 2015, p. 1019, n. k). Como não existe nenhum consenso entre os hebraístas a respeito do sentido da supracitada expressão do Salmo 9,1, a alternativa que se encontra particularmente no ATI é uma simples transcrição fonética (Francisco, 2020, p. xv).

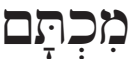

A unidade lexicográfica pְִָ̣ é um termo técnico musical de significado obscuro, sendo registrado seis vezes nos Salmos (cf. Sl 16,1; 56,1; 57,1; 58,1; 59,1; 60,1) (Even-Shoshan, 1997, p. 656).

Os hebraístas apresentam as seguintes hipóteses a respeito do item lexical em destaque: Kirst et al., comentando que é termo de sentido incerto, sugerem que seja "sobrescrito", "título", "epígrafe". Holladay define como "inscrição". Alonso Schökel se limita a dizer que se trata de tipo de salmo. Davidson supõe que o sentido seja, provavelmente, "um poema excelente" (Kirst et Al., 2014, p. 126; Holladay, 2010, p. 276; Alonso Schökel, 2004, p. 374; Davidson, 2018, p. 627). Brown, Driver e Briggs, não fornecendo nenhuma alternativa para tradução, transliteram a palavra como "mikhtam"; eles explicam que é termo técnico em títulos dos Salmos, mas de significado desconhecido (Brown, Driver e Briggs, 1996, p. 508). Koehler 
e Baumgartner definem como "inscrição" e comentam que se trata de termo técnico literário, uma "epigrama" (Koehler e Baumgartner, 2001, p. 582). Clines apresenta algumas alternativas de interpretação para o item lexicográfico em apreciação: 1. "miktam", um tipo particular de salmo; 2. "oração secreta"; 3. "inscrição sobre placa de pedra"; 4. "inscrição em letras douradas"; 5. "cântico cantado para a flauta tampada" (CLINEs, 2009, p. 220). Jastrow conceitua como "impressão", "escrito" (JAstrow, 2005, p. 785). Mackenzie e Patterson dizem que é, provavelmente, termo musical, mas de significado desconhecido. Wolf, supondo que seja "cântico de cobrir" (pecados) ou "cântico de expiação", relaciona com a palavra acádica katamu (cobrir) (Mackenzie, 1984, p. 828; Wolf, 1998, p. 756; Patterson, 1998, p. 1046).

Os textos bíblicos grego, latino e aramaico apresentam variadas interpretações a respeito da lexia: a Septuaginta $(15,1)$ interpreta como

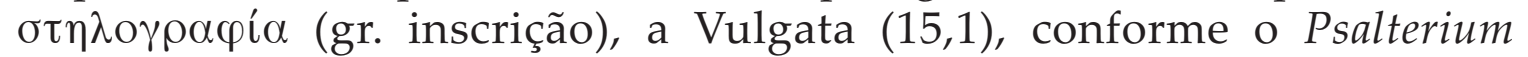
Gallicanum, como tituli inscriptio (lat. inscrição do título) e conforme o Psalterium iuxta Hebraeos, como humilis et simplicis (lat. humilde e simples)

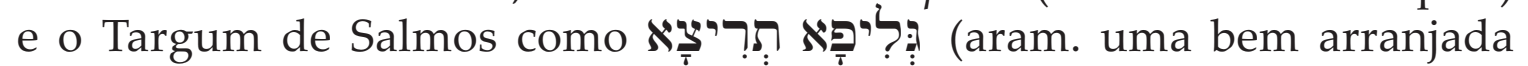
poesia). As três versões clássicas da Bíblia apresentam variedade de interpretação do item lexical em destaque neste tópico, por causa da evidente dificuldade de tradução.

Quatro dentre as sete publicações bíblicas em português selecionadas para

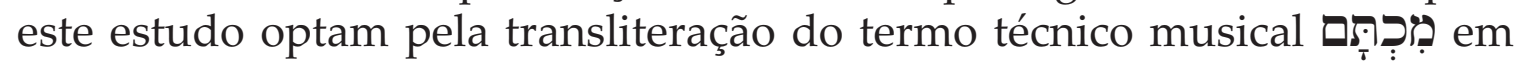
vez da tradução: ATI e TEB: "miktam"; TB: "mictão" e Tanah̆: "mihntam". Três edições escolhem algum tipo de tradução/interpretação: $B J:$ "à meia-voz"; BS: "epigrama" e NAA: "hino". Nenhuma dessas edições acata as opções encontradas nas três antigas versões da Bíblia, apresentando outras alternativas de interpretação ou mesmo usando de transliteração. No caso do $A T I$, é adotada simples transcrição fonética para o termo em relevo como "miktam", tendo por base Brown, Driver e Briggs e Clines (a primeira alternativa) (cf. acima) (Francisco, 2020, p. Xv).

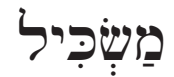

A unidade lexical פַּe é um termo técnico musical de significado desconhecido, ocorrendo dezessete vezes nos Salmos (cf. Sl 14,2; 32,1; 41,2; 42,$1 ; 44,1 ; 45,1 ; 47,8 ; 52,1 ; 53,1.3 ; 54,1 ; 55,1 ; 74,1 ; 78,1$ etc.) (Even-Shoshan, 1997, p. 718).

As seguintes hipóteses sobre o vocábulo são encontradas nas obras dicionarísticas dedicadas ao hebraico bíblico: Kirst et al., dizendo que se trata de termo técnico não esclarecido, propõem "hino litúrgico", "ensinamento" e "cântico de sabedoria adaptado à música". Holladay, informando que é termo musical não esclarecido, sugere "canção cultural", "passagem para 
o aprendizado" e "canção de sabedoria em forma de música". Alonso Schökel define, mas com dúvidas, como "maestria". Davidson estabelece como "poema de devoção" ou "poema didático" (Kirst et AL., 2014, p. 143; Holladay, 2010, p. 307; Alonso SchÖKel, 2004, p. 405; Davidson, 2018, p. 1024). Brown, Driver e Briggs sugerem "poema contemplativo" (Brown, Driver e Briggs, 1996, p. 968). Koehler e Baumgartner, não apresentando nenhuma opção para tradução, comentam que é termo técnico de sentido obscuro, significando "cântico de culto", "passagem de memória" e "cântico de sabedoria para ser cantado" (Koehler e Baumgartner, 2001, p. 641). Clines apresenta algumas escolhas de interpretação para a unidade lexical em análise: 1. "maskil", normalmente como (parte de) título de salmo, talvez denotando "salmo de sucesso"; 2. "cântico responsivo"; 3. "canção instrutiva"; 4. "instrutor" (Clines, 2009, p. 247). Kirst et al., Holladay, Alonso Schökel, Davidson, Brown, Driver e Briggs e Koehler e Baumgartner conectam o item lexicográfico à raiz verbal I שכל (hebr. [hifil] compreender, perceber, discernir, ser prudente, ser sábio), interpretando, literalmente, com um particípio masculino singular (KIRST ET AL., 2014, p. 143; Holladay, 2010, p. 307; Alonso SchöKel, 2004, p. 405; Davidson, 2018, p. 1024; Brown, Driver e Briggs, 1996, p. 968; Koenler e Baumgartner, 2001, p. 641). Mackenzie e Patterson explanam que, provavelmente, é termo musical, mas de significado desconhecido. Goldberg, transcrevendo a palavra como "maskîl", a associa aos filhos de Coré (Mackenzie, 1984, p. 828; Patterson, 1998, p. 1046; Goldberg, 1998, p. 1480).

As obras bíblicas grega, latina a aramaica interpretam o referido termo da

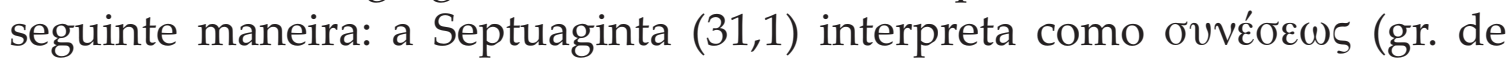
entendimento), a Vulgata $(31,1)$, conforme o Psalterium Gallicanum, como intellectus (lat. intelecto) e conforme o Psalterium iuxta Hebraeos, como eruditi

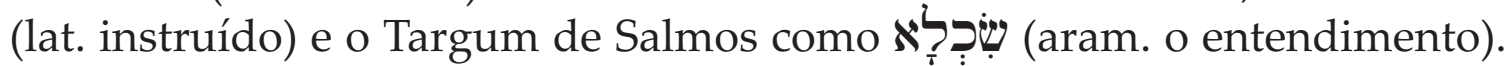
De alguma maneira, tais versões antigas da Bíblia possuem leituras similares, demonstrando algum vínculo com a raiz verbal I שכל (hebr. [hifil] compreender, perceber, discernir, ser prudente, ser sábio).

Três dentre as sete publicações bíblicas em português escolhidas para este estudo preferem a transliteração da unidade terminológica : Tanah: "maskil" e TB: "masquil". Quatro edições propõem algum tipo de tradução/interpretação: BJ: "poema"; TEB: "instrução"; $N A A$ : "salmo didátiCo"; BS: "uma percepção". Nenhuma dessas edições acata, de maneira clara, as opções encontradas nas três versões clássicas da Bíblia, apresentando outras escolhas de interpretação ou mesmo usando de transliteração. A opção adotada pela $B S$ talvez seja a única dentre tais publicações que, de alguma maneira, reflete algo da raiz verbal I שלל (hebr. [hifil] compreender, perceber, discernir, ser prudente, ser sábio). No ATI é adotada simples transcrição fonética para o item lexical em destaque como "maskil", tendo por base Clines (a primeira escolha) (Francisco, 2020, p. XVII). 


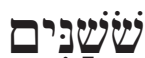

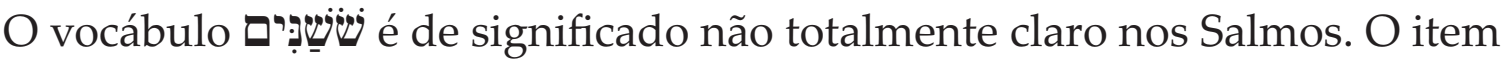

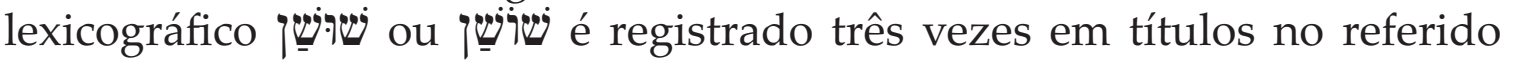
livro escriturístico (cf. Sl 45,1; 69,1; 80,1) (Even-Shoshan, 1997, p. 1129). No texto bíblico hebraico, no mencionado escrito bíblico, a palavra sempre aparece na forma plural e com alguma preposição separável:

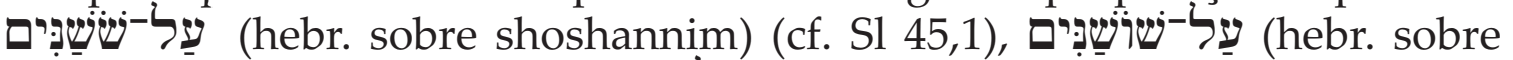

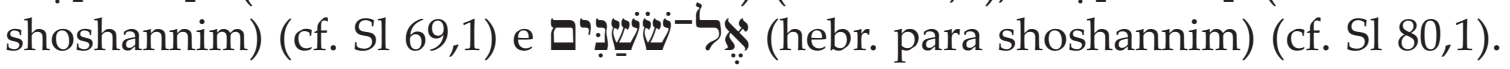

Literalmente, a referida unidade lexical significa "lírio", mas, de acordo com vários estudiosos, poderia denotar algum instrumento musical no contexto dos Salmos. Normalmente, os hebraístas demonstram incerteza em relação à sua real identificação: Kirst et al. apenas dizem que é de significado incerto nos títulos de alguns salmos. Holladay, se limitando a comentar que se trata de sobrescrito do Salmo 45,1 etc., não fornece nenhuma informação adicional a respeito e pede para que comentários sobre o assunto sejam consultados. Alonso Schökel não fornece nenhuma acepção específica para o vocábulo no contexto dos Salmos. Davidson informa que, provavelmente, seria nome de instrumento musical, parecido com um lírio (Kirst et Al., 2014, p. 247; Holladay, 2010, p. 519; Alonso SchöKeL, 2004, p. 664; DAvidson, 2018, p. 1016). Brown, Driver e Briggs, não fornecendo nenhuma acepção para tradução, explanam que é vocábulo de significado obscuro no contexto dos Salmos (Brown, Driver e Briggs, 1996, p. 1004). Koehler e Baumgartner, também não oferecendo nenhuma alternativa para tradução, explicam que nenhuma significação tem sido encontrada para a lexia em destaque; eles presumem que poderia ser derivada da palavra acádica šuššu (um sexto) e significaria "instrumento de seis cordas" (Koehler e Baumgartner, 2001, p. 1454). Clines, também não fornecendo nenhuma opção para tradução, explica que, talvez, seja uma designação de melodia; ele cogita que possa ser "O Lírio" (Sl 60,1) e "Os Lírios" (S1 45,1) (Clines, 2009, p. 454). Mackenzie supõe que seja "os lírios" e Wolf, conjecturando como "segundo o lírio", "sobre o lírio", explica que seria algum tipo de anotação musical (MACKEnzie, 1984, p. 828; Wolf, 1998, p. 1542).

As seguintes alternativas de tradução/interpretação são encontradas nas três versões bíblicas clássicas usadas neste estudo: a Septuaginta $(44,1)$ interpreta como $\tau \hat{\omega} v \dot{\alpha} \lambda \lambda \lambda_{0} \omega \theta \eta \sigma o \mu \dot{\varepsilon} v \omega v$ (gr. dos que serão mudados), a Vulgata $(44,1)$, segundo o Psalterium Gallicanum, como qui commutabuntur (lat. que hão de ser mudados) e segundo o Psalterium iuxta Hebraeos, como pro liliis (lat. pelos lírios). O Targum de Salmos possui um texto longo e interpretativo, não sendo possível identificar alguma palavra do texto bíblico aramaico que possa corresponder ao texto bíblico hebraico. Assim, os textos bíblicos grego e latino, este último conforme o Psalterium Gallicanum, apresentam a mesma interpretação. $\mathrm{O}$ texto latino, mas segun- 
do o Psalterium iuxta Hebraeos, apresenta outra opção de interpretação. As versões grega e latina, esta última segundo o Psalterium Gallicanum,

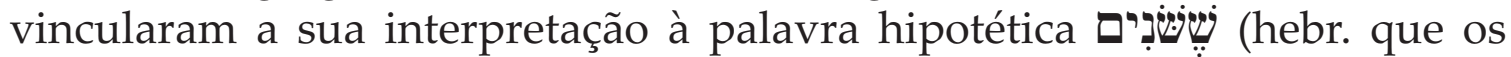
que são mudados), que é particípio masculino plural da raiz verbal שנה (hebr. [qal] modificar-se, repetir-se), junto com a partícula relativa שֶ (hebr. que). Contudo, a versão latina, mas conforme o Psalterium iuxta Hebraeos,

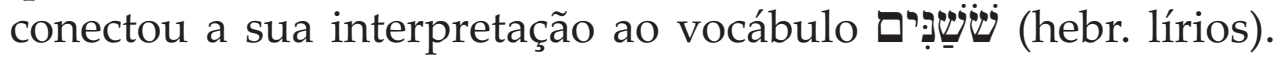

As várias edições da Bíblia em língua portuguesa ora adotam transcrição

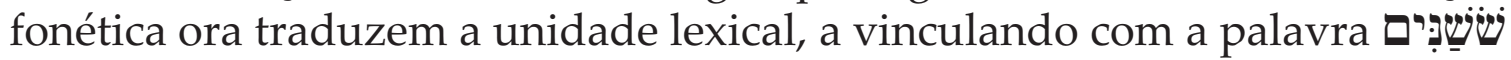
(hebr. lírios): ATI: "shoshannim"; TB: "sosanim" e Tanah: "shoshanim". BJ e NAA "os lírios"; BS e TEB: "os lírios". Portanto, nenhuma dessas publicações faz a opção que é registrada na Septuaginta e na Vulgata, esta última de acordo com a recensão Psalterium Gallicanum. Na TEB há uma nota de rodapé informando que a lexia designaria algum instrumento musical (TEB, 2015, p. 1057, n. y). Por fim, o vocábulo é simplesmente transliterado como "shoshannim" no ATI. Tal procedimento é em virtude de não haver alternativa de tradução que possa ser segura ou definitiva (Francisco, 2020, p. XIX).

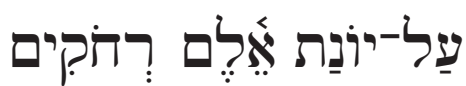

A expressão עַל é muito obscura, sendo registrada unicamente no Salmo 56,1 (Even-Shoshan, 1997, p. 459). A locução é formada pelos seguintes itens lexicais: a preposição separável עַ (hebr. sobre), o substantivo em estado construto (hebr. pomba de), o substantivo em

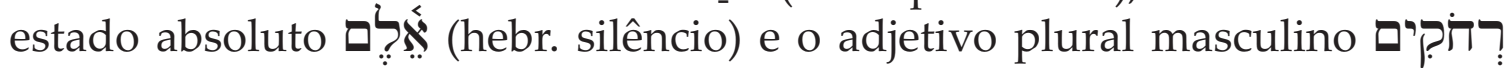
(hebr. distantes). O sintagma inteiro pode ter a seguinte tradução literal: "sobre pomba de silêncio distantes" (?!).

Os hebraístas apresentam variadas conjecturas a respeito da interpretação da referida expressão: Holladay e Koehler e Baumgartner se limitam a informar que se trata de texto que aparece em cabeçalho do Salmo 56,1 (Holladay, 2010, p. 187; Koehler e Baumgartner, 2001, p. 402). Davidson cita a seguinte conjectura proposta por Wilhelm Gesenius: "a pomba silenciosa entre estrangeiros" (Davidson, 2018, p. 165). Brown, Driver e Briggs explanam que, provavelmente, seria nome de melodia e significaria "para a pomba de distantes terebintos" (Brown, Driver e Briggs, 1996, p. 401-402). Koehler e Baumgartner e Clines

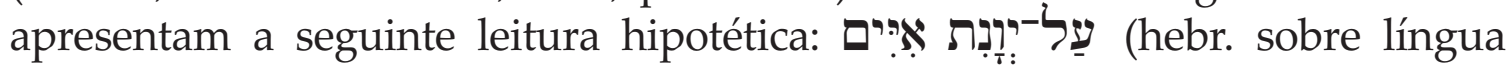
grega de [distantes] costas litorais) (?!) (KoeHLer e Baumgartner, 2001, p. 402; Clines, 2009, p. 150). A suposição fornecida por Mackenzie é "a pomba dos terebintos distantes" (MACKENZIE, 1984, p. 828).

As seguintes interpretações são apresentadas pelas versões grega, latina

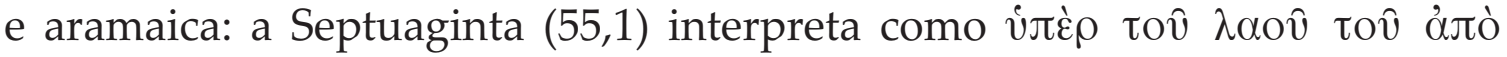
$\tau \hat{\omega} v \dot{\alpha} \gamma i \omega v \mu \varepsilon \mu \alpha \kappa \rho v \mu \mu \varepsilon \dot{v} \mathrm{v} v$ (gr. sobre o povo o que estava longe das coisas 
santas), a Vulgata $(55,1)$, conforme o Psalterium Gallicanum, como pro populo qui a sanctis longe (lat. pelo povo que se achava longe dos santos) e conforme o Psalterium iuxta Hebraeos, como pro columba muta eo quod procul abierit (lat. pela pomba muda, que lá para longe se afastou) e o Targum de Salmos como

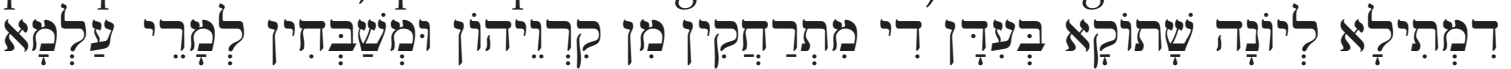
(aram. que comparar com a pomba, o silêncio em tempo em que os que estão distantes das cidades deles e os que retornam para os senhores de eternidade). Assim, cada versão bíblica clássica oferece alguma interpretação distinta concernente à locução do cabeçalho do Salmo 56,1. A única palavra que ocorre nos quatro textos bíblicos clássicos é "longe/distante" (quatro vezes). Porém, as lexias "povo' (duas vezes), "coisas santas/santos" (duas vezes), "pomba" (duas vezes) e "silêncio/muda" (duas vezes) aparecem em uma ou outra versão bíblica antiga.

Duas edições em português optam em transcrever a locução de maneira completa: ATI: "al-yonate elem rehoquim" e TEB: "'al yônat êlem rehoqim". Duas publicações também transcrevem, mas parcialmente: TB: "a jonate-elém-reoquim" e Tanahl: "sobre ionat-élem-rehokim". Três obras preferem oferecer alguma opção de tradução: BJ: "sobre 'a opressão dos príncipes distantes'"; $B S:$ "segundo a pomba dos distantes emudecidos" e NAA: "segundo a melodia 'a pomba nos terebintos distantes'". Na nota de rodapé da TEB constam duas interpretações: "sobre a pomba do silêncio dos que estão longe" e "sobre a pomba dos deuses longínquos". De acordo com tal edição bíblica, tais textos, talvez, seriam indicações de melodia na qual se cantava o salmo (TEB, 2015, p. 1068, n. y). Seja como for, não há unanimidade entre os estudiosos em relação ao significado exato da expressão do referido salmo. No ATI a supracitada locução é simplesmente transcrita como "al-yonate elem rehoquim", por ser muito enigmática. Além do mais, as opiniões e sugestões não se mostraram seguras ou definitivas o suficiente para serem acatadas na citada edição bíblica em língua portuguesa (Francisco, 2020, p. xIX).

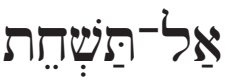

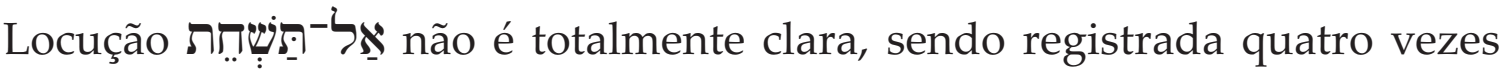
nos Salmos (cf. Sl 57,1; 58,1; 59,1; 75,1) (Even-Shoshan, 1997, p. 1133). Normalmente, a referida expressão é traduzida como "não destruas" em diversas edições da Bíblia. Em termos morfológicos, a locução é formada pelo advérbio de negação (hebr. não) e pelo item verbal (h) (hebr. destruas), que é derivado da raiz verbal ששחת (hebr. destruir, danificar), na conjugação hifil, segunda pessoa masculina do singular do tempo imperfeito, com função de jussivo, podendo ser traduzida, literalmente, como "que não destruas". ${ }^{5} \mathrm{O}$ software bíblico Paratext UBS Translation Software

\footnotetext{
${ }^{5}$ Jussivo (lat. jussus: o que recebeu ordem, o que obedeceu ordem; particípio passivo do verbo jubeo: ordenar, dar ordem, mandar): forma verbal do hebraico bíblico, sendo uma das funções do tempo
} 
translitera como "al-tashcheth". O software bíblico BibleWorks fornece a classificação como uma forma verbal (cf. acima).

Concernente à expressão no título do Salmo 57,1, as seguintes opiniões são apresentadas pelos hebraístas: Kirst et al. esclarecem que se trata de expressão com significado incerto. Holladay explica que é termo inexplicado. Brown, Driver e Briggs traduzem como "que não destruas" e explanam que seria tema de uma antiga canção ou melodia, mas expressam incerteza. Koehler e Baumgartner comentam que indicaria palavras de abertura de uma canção, um começo que serviria como exemplo para o acompanha-

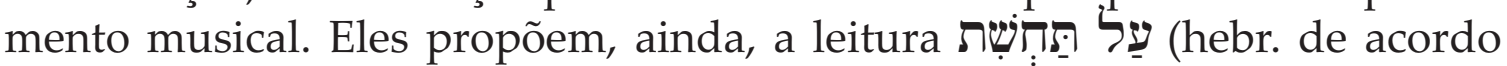
com tahshit), que seria uma melodia particular ou um estilo de apresentação. Tal suposição poderia ser interpretada como "ao estilo de Tahash". Clines verte como "que não destruas" e elucida que se trata de título de determinados salmos, talvez indicando melodia de uma canção (KIRST ET al., 2014, p. 249; Holladay, 2010, p. 521; Brown, Driver e Briggs, 1996, p. 1008; Koehler e Baumgartner, 2001, p. 1471-1472; Clines, 2009, p. 457). Para Mackenzie e Fontinoy, a locução poderia ser traduzida como "não destruas" (Mackenzie, 1984, p. 828; Fontinoy, 2013, p. 941).

As versões bíblicas grega, latina e aramaica lidam com a locução em relevo

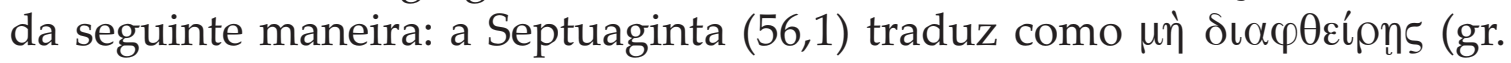
que não destruas), a Vulgata (56,1), de acordo com o Psalterium Gallicanum, como ne disperdas (lat. não destruas) e de acordo com o Psalterium iuxta Hebraeos, como non disperdas (lat. não destruas) e o Targum de Salmos

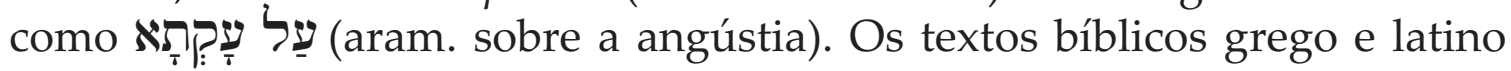
concordam entre si ao apresentarem a mesma tradução, mas o texto bíblico aramaico possui leitura distinta.

Quatro publicações bíblicas em língua portuguesa apresentam maneiras similares de transliteração para a locução em destaque neste tópico: ATI: "al-tashhete"; TB: "al-tasete"; TEB: "'al-tashehet" e Tanah: "al tash'het". Três edições, ao contrário, optam em apresentar a mesma opção de tradução: BJ e NAA: "não destruas"; BS: "não destruas!". Tais obras refletem a alternativa de tradução que é verificada na Septuaginta e na Vulgata. Na $T E B$, há uma nota de rodapé em que consta a tradução "não destruas", explicando que talvez seria palavras iniciais de uma canção (TEB, 2015, p. 1069 , n. f). Por fim, no ATI a locução é simplesmente transcrita, de maneira fonética, como "al-tashhete". O motivo de tal procedimento é que não há opinião segura ou definitiva, ainda, entre os hebraístas para tradução do supracitado trecho do Salmo 57,1 (Francisco, 2020, p. xx).

imperfeito, terceira e segunda pessoas do singular, expressando vontade, desejo, intenção, pedido, correspondendo ao modo subjuntivo do português (Gesenius, Kautzsch e Cowley, 1910, § $48 \mathrm{f}, \mathrm{h}$, p. 130-131; Joüon e Muraoka, 2009, § 46 a, p. 127; WaltKe e O’Connor, 2006, § 34.1 a, p 564 e $\S 34.2 .1$ a, p. 566; Gaffiot, 2000, p. 879 e 885; Santos Saraiva, 2000, p. 644 e 649). 


\section{עַל-שׁוּשֶן עִדרוּת}

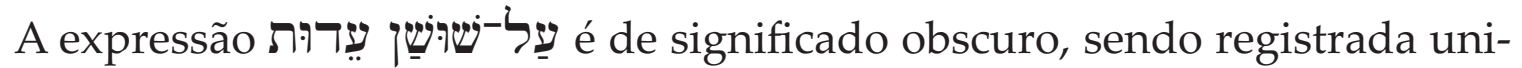
camente no Salmo 60,1 (Even-Shoshan, 1997, p. 1128). As duas unidades

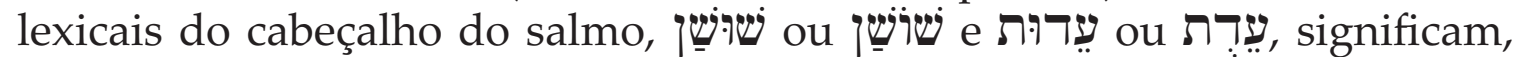
literalmente, "lírio" e "testemunho", respectivamente (KIRST ET AL., 2014, p. 173 e 247; Holladay, 2010, p. 377 e 519; Alonso SchöKel, 2004, p. 480 e 664; Davidson, 2018, p. 869 e 1016; Brown, Driver e Briggs, 1996, p. 730 e 1004; Koenler e Baumgartner, 2001, p. 790 e 1454; Clines, 2009, p. 311 e 454$)$.

Alguns hebraístas apresentam algumas explicações a respeito da locução em realce: Brown, Driver e Briggs explicam que se trata de melodia cuja primeira linha compara lei como testemunho para uma flor de escolha. Koehler e Baumgartner informam que o significado é incerto nos títulos dos Salmos. Clines fornece a transliteração "shushan eduth", que talvez signifique "lírio do testemunho" (Brown, Driver e Briggs, 1996, p. 730; Koehler e Baumgartner, 2001, p. 791; Clines, 2009, p. 311). Mackenzie fornece a seguinte interpretação: "os lírios do testemunho" (MACKEnZIE, 1984, p. 828).

As versões clássicas bíblicas apresentam as seguintes interpretações a respeito do trecho do cabeçalho do Salmo 60,1: a Septuaginta $(59,1)$ interpreta

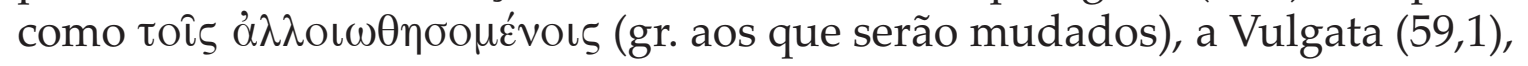
conforme o Psalterium Gallicanum, como his qui inmutabuntur (lat. para aqueles que hão de ser mudados) e conforme o Psalterium iuxta Hebraeos, como pro liliis testimonium (lat. para o testemunho dos lírios) e o Targum

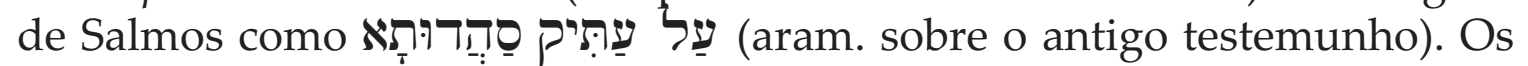
textos bíblicos grego, latino e aramaico tentam apresentar algum significado à locução, sendo que as versões grega e latina, mas segundo o Psalterium Gallicanum, oferecem a mesma solução, enquanto as versões latina, conforme o Psalterium iuxta Hebraeos, e aramaica, possuem alternativa que reflete, de certa maneira, o texto bíblico hebraico.

Da mesma forma como nos casos dos termos técnicos encontrados nos títulos de alguns salmos analisados anteriormente, quatro publicações da Bíblia em português adotam transcrição fonética em vez de alguma escolha de tradução: ATI: "al-shushan edute"; TB: "susã edute"; TEB: "'al-shushan 'edut'" e Tanah: "shushan edut". Três edições oferecem alguma alternativa de tradução/interpretação: BJ: "o lírio é o preceito"; BS: "conforme o lírio da norma" e NAA: "segundo a melodia 'o lírio do testemunho'". A TEB dá em nota de rodapé a tradução "sobre "um lírio (é) o testemunho"” (TEB, 2015, p. 1072, n. e). As publicações BJ, BS e NAA, de alguma maneira, refletem a opção encontrada na Vulgata, mas de acordo com o Psalterium iuxta Hebraeos (cf. acima). Por último, a expressão é simplesmente transliterada como "al-shushan edute" no ATI. Tal decisão é por causa de não 
haver opção de tradução que possa ser realmente segura ou determinante para ser acatada na referida edição bíblica (Francisco, 2020, p. XXI).

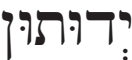

Tal item lexicográfico ידוּרתין: aparece três vezes em títulos nos Salmos (cf. Sl 39,1; 62,1; 77,1) (Even-Shoshan, 1997, p. 431). No texto bíblico hebraico, tal unidade lexical aparece sempre com alguma preposição inseparável ou

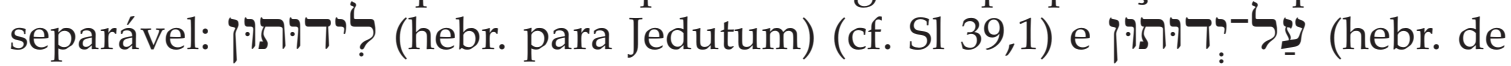
acordo com Jedutum) (Sl 62,1; 77,1).

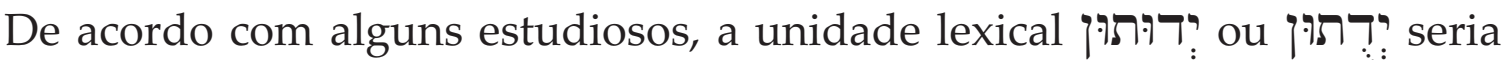
termo técnico musical nos Salmos, segundo outros, seria nome próprio masculino, tendo relação com Jedutum em 1Crônicas (cf. 1Cr 25,1.6; 16,42 etc.), 2Crônicas (cf. 2Cr 5,12; 35,15 etc.) e Neemias (cf. Ne 11,7): Kirst et al., Holladay, Davidson e Clines classificam apenas como nome próprio masculino, sem especificar mais. Alonso Schökel se limita a estabelecer como nome próprio "Iditun" e não fornece maiores explicações (KIRST et AL., 2014, p. 85; Holladay, 2010, p. 183; Alonso SchöKel, 2004, p. 745; Davidson, 2018, p. 503; Clines, 2009, p. 146). Brown, Driver e Briggs explanam que, além de nome próprio masculino, no contexto dos Salmos, seria termo musical, significando "à maneira (do grupo de cantores) de Jedutum" (Brown, Driver e Briggs, 1996, p. 393). Koehler e Baumgartner, não fornecendo nenhuma significação, dizem que se trata de termo técnico musical (Koehler e Baumgartner, 2001, p. 389-390). Alexander explica que o referido nome, no cabeçalho dos Salmos 39,1; 62,1 e 77,1, é, muito provavelmente, referência a Jedutum ou a seu grupo, na condição de músicos de deveriam apresentar o salmo de maneira instrumental ou vocal (AleXANDer, 1998, p. 596-597).

As antigas versões da Bíblia vertem o trecho da seguinte maneira: a Septuaginta $(61,1)$ verte como $\dot{\tau} \tilde{\varepsilon} \rho$ I $\delta \iota \theta o v v$ (gr. sobre Idithun), a Vulgata $(61,1)$, de acordo com o Psalterium Gallicanum, como pro Idithun (lat. para Iditum) e de acordo com o Psalterium iuxta Hebraeos, como per Idithun (lat.

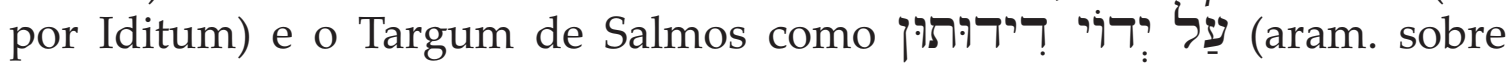
as mãos de Jedutum). De uma maneira ou outra, tais versões bíblicas clássicas refletem o texto bíblico hebraico, apresentando, praticamente, a mesma escolha de tradução.

As diversas edições da Bíblia em língua portuguesa apresentam a mesma opção de interpretação, mesmo com alguma diferença entre elas na tradução do item lexical: ATI: "de acordo com Jedutum"; TB: "segundo Jedutum"; Tanah: “com Iedutun"; TEB: "segundo Iedutun"; BJ: “...Iditun"; $B S:$ "segundo Iditun" e NAA: "segundo a melodia de Jedutum". Na nota de rodapé da TEB consta a explicação de que se trata de um nome de um grupo de levitas encarregado do cântico ou da supervisão das portas do 
templo (TEB, 2015, p. 1050, n. r). Por causa das incertezas, no ATI o item lexicográfico é tratado com um nome próprio masculino, talvez relacionado com o grupo de levitas cantores do grupo de Jedutum (Francisco, 2020, p. XXII). Para concluir, Gottwald explica que determinados nomes, como Jedutum, Heman e Etã, provavelmente, poderiam indicar que as peças literárias musicais dos Salmos faziam parte do repertório de corporações de músicos da época do segundo templo (GotTwald, 1988, p. 497). Mackenzie explana que alguns de tais nomes poderiam ser nominações de corporações corais do templo ou poderiam indicar que são denominações de coleções de salmos pertencentes a corporações corais particulares (MACKENZIE, 1984, p. 827).

\section{Conclusão}

O quadro abaixo fornece uma classificação dos treze termos técnicos musicais encontrados no Salmos elencados e analisados neste breve estudo. Nessa tabela, constam os itens terminológicos, a referência bíblica em que aparecem e uma possível classificação, mesmo que conjectural:

\begin{tabular}{|c|c|c|}
\hline termo técnico musical & texto bíblico & significado \\
\hline كَלְלָה & S1 3,$3 ; 9,17 ; 21,3$ etc. & indicação de pausa? \\
\hline נְִחִילְה & S1 5,1 & instrumento musical? \\
\hline 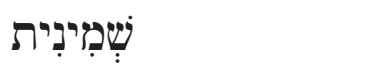 & Sl 6,$1 ; 12,1$ etc. & instrumento musical? \\
\hline שִשְiּיוֹן & S1 7,1 etc. & modelo de cântico? \\
\hline 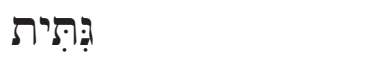 & $\mathrm{S} 18,1 ; 81,1 ; 84,1$ etc. & instrumento musical? \\
\hline עַלְמוּת לַבְּן & Sl 9,1 & melodia de cântico? \\
\hline מִכְְָתם & Sl 16,$1 ; 56,1 ; 57,1$ etc. & título musical? \\
\hline 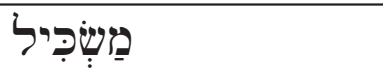 & S1 14,$2 ; 32,1 ; 42,1$ etc. & modelo de cântico? \\
\hline 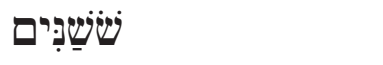 & Sl 45,$1 ; 69,1 ; 80,1$ etc. & instrumento musical? \\
\hline 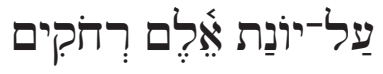 & Sl 56,1 & melodia de cântico? \\
\hline אַל-תְַּשׁחת & Sl 57,1; 58,1; 59,1 etc. & melodia de cântico? \\
\hline עַל-שׁוּשֶׁן עֵדוּת & S1 60,1 & melodia de cântico? \\
\hline ירוּתוּן & S1 39,1; 62,1; 77,1 etc. & modelo de cântico? \\
\hline
\end{tabular}


A terceira coluna mostra as possibilidades de classificação de cada item lexical do hebraico bíblico, que pertence ao campo da música e que são comentados neste texto. A classificação geral é a seguinte: indicação de pausa:1; instrumento musical: 4; modelo de cântico: 3; melodia de cântico: 4 e título musical: 1 . Possivelmente, tal arranjo classificatório seja plausível em relação ao significado de cada termo técnico musical. Além do mais, o quadro acima demonstra que todas as unidades lexicográficas não possuem acepção que possa ser estabelecida de maneira definitiva ou mesmo ser indiscutível. Consequentemente, as edições da Bíblia em língua portuguesa apresentam variadas alternativas de tradução, como se demonstrou por meio do presente artigo.

É possível perceber que, por causa da incerteza de tradução dos vocábulos técnicos nos Salmos, nas edições da Bíblia em português ora é adotada transliteração ora é adotada tradução/interpretação. O quadro a seguir mostra, de maneira sinóptica, tal constatação nas sete publicações bíblicas escolhidas para este estudo:

\begin{tabular}{|c|c|c|}
\hline termo técnico musical & transliteração & tradução/interpretação \\
\hline סְלְה & $A T I, T B$ & $B J, B S, T E B^{6}$ \\
\hline נִּחִילְה & ATI & $B J, B S, N A A$, Tanah, $T B, T E B$ \\
\hline 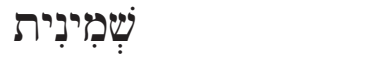 & $A T I, T B$ & $B J, B S, N A A$, Tanah, TEB \\
\hline 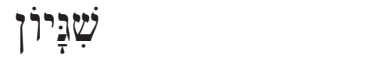 & ATI, Tanah, TB & $B J, B S, N A A, T E B$ \\
\hline 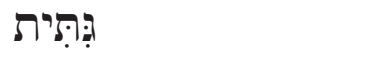 & $A T I, T B, T E B$ & $B J, B S, N A A$, Tanah \\
\hline עַלְמוּת לַבַּן & $A T I, T B, T E B$ & $B J, B S, N A A$, Tanah \\
\hline 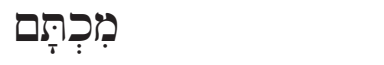 & $A T I$, Tanah, TB, TEB & $B J, B S, N A A$ \\
\hline 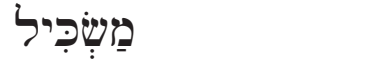 & ATI, Tanah, TB & $B J, B S, N A A, T E B$ \\
\hline 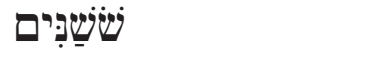 & ATI, Tanah, TB & $B J, B S, N A A, T E B$ \\
\hline עַל-יוֹנַת אַלִם רְחזקים & ATI, Tanah, TB, TEB & $B J, B S, N A A$ \\
\hline 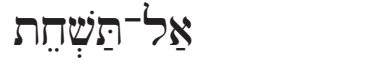 & $A T I$, Tanah, $T B, T E B$ & $B J, B S, N A A$ \\
\hline עַל-שׁוּשׁׁן עַדרוּת & ATI, Tanah, TB, TEB & $B J, B S, N A A$ \\
\hline :דירוּתון & & $\begin{array}{l}A T I, B J, B S, N A A, \\
\text { Tanah, } T B, T E B\end{array}$ \\
\hline
\end{tabular}

\footnotetext{
${ }^{6}$ As edições bíblicas Tanah e NAA não apresentam nenhuma opção de transcrição fonética ou tradução/interpretação para o termo técnico musical ợ não são mencionadas na primeira linha da presente tabela comparativa.
} 
Concluindo este artigo, as diversas publicações bíblicas em língua portuguesa não oferecem um quadro absolutamente definitivo de tradução dos termos técnicos relacionados com a música no texto bíblico hebraico. Por meio das várias versões bíblicas em idioma lusitano, é possível constatar que há diversidade de soluções/possibilidades para os itens terminológicos que são registrados nos Salmos. Às vezes, algumas edições da Bíblia refletem as alternativas que são encontradas na Septuaginta e na Vulgata. As opções dos textos bíblicos grego e latino se tornaram, de alguma maneira, tradicionais em traduções bíblicas para o português, como, por exemplo, as palavras "pausa" (cf. Sl 3,3; 9,17; 21,3 etc.), "oitava/oito cordas" (cf. Sl 6,1; 12,1 etc.), "os lagares" (cf. Sl 8,1; 81,1; 84,1), "não destruas" (cf. S1 57,1; 58,1; 59,1 etc.) e "Jedutum" (cf. Sl 39,1; 62,1; 77,1 etc.).

A preferência pela transcrição fonética, como se verifica continuamente no ATI, como nos exemplos "nehilote" (cf. Sl 5,1), "shiggaion" (cf. Sl 7,1), "sheminite" (cf. Sl 6,1; 12,1 etc.), "miktam" (cf. Sl 16,1; 56,1; 57,1 etc.), "maskil" (cf. Sl 14,2; 32,1; 42,1 etc.), entre outras exemplificações, é em virtude da complexidade ou da impossibilidade de se obter algum correspondente exato em português, daí, a escolha pela transliteração. $\mathrm{O}$ expediente adotado no ATI segue a norma da língua portuguesa para aquelas palavras e nomes de procedência hebraica, tais como Isaque, Baruque, Mesaque, Elate, Talmude etc. (Francisco, 2014, p. 118; idem, 2020, p. XII, XIII).

Por fim, tanto a escolha pela transliteração quanto a opção pela tradução/ interpretação são admissíveis em uma tradução bíblica, principalmente quando o tradutor se depara com um grupo específico de vocábulos de acepção complicada e que exige profunda e ampla pesquisa na literatura dedicada especialmente ao hebraico bíblico. No presente artigo, pôde-se perceber que tanto as versões bíblicas clássicas quanto as edições bíblicas modernas tiveram que lidar com tal problemática de natureza semântica e todas elas tentaram solucionar, de uma maneira ou outra, a complexa situação de tradução do texto bíblico hebraico.

\section{Referências}

Alexander, R. H. yedûtûn, Jedutum. In: Harris, R. L.; Archer, Jr., G. L.; WaltKe, B. K. (Org.). Dicionário Internacional de Teologia do Antigo Testamento. São Paulo: Vida Nova, 1998, p. 596-597.

Almeida, J. F. de (Trad.). Bíblia de Estudos Nova Almeida Atualizada. Barueri: Sociedade Bíblica do Brasil, 2017.

Alonso Schökel, L. (Ed.). Dicionário Bíblico Hebraico-Português. 3. ed. São Paulo: Paulus, 2004.

BibleWorks 8: Software for Biblical Exegesis and Research. Norfolk: Bibleworks, LLC, 2008. 
BÍBLIA de Jerusalém. São Paulo: Paulus, 2002.

BÍBLIA Sagrada: tradução brasileira. Barueri: Sociedade Bíblica do Brasil, 2010.

BÍBLIA. Tradução Ecumênica. 2. ed. São Paulo: Loyola, 2015.

Brotzman, E. R.; Tully, E. J. Old Testament Textual Criticism: a Practical Introduction. 2. ed. Grand Rapids: Baker Academic, 2016.

Brown, F.; Driver, S. R.; Briggs, C. A. (Ed.). The Brown-Driver-Briggs Hebrew and English Lexicon. Peabody: Hendrickson, 1996.

Clines, D. J. A. (Ed.). The Concise Dictionary of Classical Hebrew. Sheffield: Sheffield Phoenix Press, 2009.

Coppes, L. J. nehîlâ. In: Harris, R. L.; Archer, Jr., G. L.; Waltke, B. K. (Orgs.). Dicionário Internacional de Teologia do Antigo Testamento. São Paulo: Vida Nova, 1998. p. 948.

Davidson, B. (Ed.). Léxico Analítico Hebraico e Caldaico: todas as palavras e flexões do AT organizadas alfabeticamente e com análises gramaticais. São Paulo: Vida Nova, 2018.

Fischer, A. A. O Texto do Antigo Testamento. Edição Reformulada da Introdução à Bíblia Hebraica de Ernst Würthwein. Barueri: Sociedade Bíblica do Brasil, 2013.

Fontinoy, C. Música na Bíblia. In: Centro Informática e Bíblia Abadia de MareDsous (Dir.). Dicionário Enciclopédico da Bíblia. São Paulo: Paulus: Paulinas: Loyola, 2013. p. 939-941.

Francisco, E. de F. Manual da Bíblia Hebraica: introdução ao texto massorético. Guia introdutório para a Biblia Hebraica Stuttgartensia. 3. ed. São Paulo: Vida Nova, 2008.

Francisco, E. de F. A tradução do texto Bíblico Hebraico: discussão sobre situações de dificuldades textuais. In: Carneiro, M. (Org.). Bíblia e Cultura: tradição, tradução e exegese. Debatendo as diferentes leituras da Bíblia. São Paulo: Fonte Editorial, 2014. p. 115-121.

Francisco, E. de F. (Trad.). Antigo Testamento Interlinear Hebraico-Português. Escritos. Barueri: Sociedade Bíblica do Brasil, 2020. v. 4.

Gaffiot, F. (Ed.). Le Grand Gaffiot Dictionnaire Latin-Français. Paris: Hachette, 2000.

Gesenius, W.; Kautzsch, E.; Cowley, A. E. Gesenius' Hebrew Grammar. 2. ed. Oxford: Clarendon Press, 1910.

Goldberg, L. maskîl. In: Harris, R. L.; Archer, Jr., G. L.; Waltke, B. K. (Org.). Dicionário Internacional de Teologia do Antigo Testamento. São Paulo: Vida Nova, 1998. p. 1480.

Gorodovits, D.; Fridlin, J. (Ed.). Tanah Completo Hebraico e Português: texto hebraico baseado no Códex de Alepo e tradução baseada no hebraico e à luz do Talmud e das fontes judaicas. São Paulo: Sêfer, 2018.

Gottwald, N. K. Introdução Socioliterária à Bíblia Hebraica. 2. ed. Coleção Bíblia e Sociologia 5. São Paulo: Paulus, 1988.

Grenzer, M. (Trad.). A Bíblia: Salmos. São Paulo: Paulinas, 2017. 
Holladay, W. L. (Ed.). Léxico Hebraico e Aramaico do Antigo Testamento. São Paulo: Vida Nova, 2010.

Houaiss, A.; Villar, M. S. (Ed.). Dicionário Houaiss da Língua Portuguesa. Rio de Janeiro: Objetiva, 2009.

Jastrow, M. (Ed.). A Dictionary of the Targumim, the Talmud Babli and Yerushalmi and the Midrashic Literature. Peabody: Hendrickson, 2005. v. 1 e 2.

Joüon, P.; Muraoka, T. A Grammar of Biblical Hebrew. 2. ed. Roma: Gregorian \& Biblical Press, 2009. (Subsidia Biblica, 27).

KHAN, G. A Short Introduction to the Tiberian Masoretic Bible and its Reading Tradition. 2. ed. Piscataway: Gorgias Press, 2013. (Gorgias Handbooks, 25).

Kirst, N. et al. (Ed.). Dicionário Hebraico-Português \& Aramaico-Português. 29. ed. São Leopoldo-Petrópolis: Sinodal: Vozes, 2014.

Koenler, L.; Baumgartner, W. (Ed.). The Hebrew and Aramaic Lexicon of the Old Testament: Study Edition. Leiden-Boston-Köln: Brill, 2001. 2 v.

Lipiński, É. Salmos, Livro dos. In: Centro: Informática e Bíblia Abadia de MareDsous (Dir.). Dicionário Enciclopédico da Bíblia. São Paulo: Paulus: Paulinas: Loyola, 2013. p. 1203-1208.

Mackenzie, J. L. Salmos. In: Mackenzie, J. L. Dicionário Bíblico. 2. ed. São Paulo: Paulinas, 1984. p. 827-831.

Martín Contreras, E.; Seijas de los Ríos-Zarzosa, M. G. Masora: La Transmisión de la Tradición de la Biblia Hebrea. Instrumentos para el estudio de la Biblia XX. Estella (Navarra): Verbo Divino, 2010.

Ofer, Y. The History and Authority of the Aleppo Codex. In: Glatzer, M. (Ed.). Jerusalem Crown: The Bible of the Hebrew University of Jerusalem. Companion Volume. Jerusalem-Basel: N. Ben Zvi Enterprises-The Karger Family Fund, 2002. p. 25-50.

Ofer, Y. The Masora on Scriptures and Its Methods. Fontes et Subsidia ad Bibliam pertinentes 7. Berlin-Boston: De Gruyter, 2019.

Paratext UBS Translation Software. 8.0.100.4. New York: United Bible Socities, 2019.

Patterson, R. D. selâ. In: Harris, R. L.; Archer, Jr., G. L.; Waltke, B. K. (Org.). Dicionário Internacional de Teologia do Antigo Testamento. São Paulo: Vida Nova, 1998. p. 1046.

Rahlfs, A.; Hanhart, R. (Ed.). Septuaginta: Id est Vetus Testamentum graece iuxta LXX interpretes - Editio altera. Stuttgart: Deutsche Bibelgesellschaft, 2006. v. 1 e 2.

Santos Saraiva, F. R. dos (Ed.). Novíssimo Dicionário Latino-Português: etimológico, prosódico, histórico, geográfico, mitológico, biográfico, etc. 11. ed. Rio de Janeiro: Garnier, 2000.

Tov, E. Textual Criticism of the Hebrew Bible. 3. ed. Minneapolis: Fortress Press, 2012.

Tov, E. Crítica Textual da Bíblia Hebraica. Niterói: BV Books, 2017. 
Waltke, B. K.; O'Connor, M. P. Introdução à Sintaxe do Hebraico Bíblico. São Paulo: Cultura Cristã, 2006.

Weber, R.; Gryson, R. (Eds.). Biblia Sacra iuxta Vulgatam Versionem. 5.ed. Stuttgart: Deutsche Bibelgesellschaft, 2007.

Wolf, H. gittît, gitite. In: Harris, R. L.; Archer, Jr., G. L.; Waltke, B. K. (Orgs.). Dicionário Internacional de Teologia do Antigo Testamento. São Paulo: Vida Nova, 1998. p. 589.

Wolf, H. mictam. In: Harris, R. L.; Archer, Jr., G. L.; Waltke, B. K. (Orgs.). Dicionário Internacional de Teologia do Antigo Testamento. São Paulo: Vida Nova, 1998. p. 756.

Wolf, H. shôshan, lírio. In: Harris, R. L.; Archer, Jr., G. L.; Waltke, B. K. (Orgs.). Dicionário Internacional de Teologia do Antigo Testamento. São Paulo: Vida Nova, 1998. p. 1541-1542.

Wolf, H. shemînî, shemînît. In: Harris, R. L.; Archer, Jr., G. L.; Waltke, B. K. (Org.). Dicionário Internacional de Teologia do Antigo Testamento. São Paulo: Vida Nova, 1998. p. 1585.

WürthweIn, E. The Text of the Old Testament: an Introduction to the Biblia Hebraica. 2. ed. Grand Rapids: Eerdmans, 1995.

Artigo submetido em 24.01.2020 e aprovado em 13.04.2020.

Edson de Faria Francisco é Doutor (2008) com Pós-Doutorado (2011) em Língua Hebraica, Literatura e Cultura Judaicas pela Universidade de São Paulo (USP); é linguista e professor do Departamento de Bíblia da Universidade Metodista de São Paulo (UMESP), responsável pelas disciplinas Hebraico Bíblico e Grego Bíblico. Orcid.org/0000-0002-7224-9601. E-mail: edson.francisco@metodista.br

Endereço: Universidade Metodista de São Paulo (UMESP)

Edifício Gama

Rua do Sacramento, 230

Rudge Ramos

09640-000 São Bernardo do Campo - SP 